\title{
Table of legislation
}

\section{EU LEGISLATION}

\section{Decisions}

Commission Decision 2000/520/EC of 26 July 2000 pursuant to Directive 95/46/EC of the European

Parliament and of the Council on the adequacy of the protection provided by the safe harbour privacy principles and related frequently asked questions issued by the US Department of Commerce, OJ L215/7, 25.08.2000 [Safe Harbour Decision] .... xix, 159, 162-4, 169, 171-3, 198, 250, 254, 256

Art.1(1) ...................................... 171

Art.2 ….................................... 172

Art.3 …………......................... 198

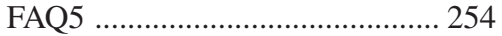

Rec.2 …........................................ 163

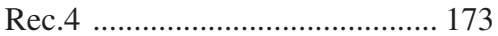

Commission Decision 2002/16/EC of

27 December 2001 on standard contractual clauses for the transfer of personal data to processors established in third countries, under Directive 95/46/EC , OJ L6/52, 10.01.2002 [2001

SCCs] $19,190,191$

Rec.8 191

Commission Decision 2004/915/EC of

27 December 2004 amending

Decision 2001/497/EC as regards the introduction of an alternative set of standard contractual clauses for the transfer of personal data to third countries, OJ L385/74, 29.12.2004 [2004 SCCs] ....... 190 Commission Decision 2010/87/EU of 5 February 2010 on standard contractual clauses for the transfer of personal data to processors established in third countries under Directive 95/46/EC of the European Parliament and of the Council, OJ L39/5, 12.02.2010 [2010 Decision, 2010 SCCs] ... xv, 157, 178-9, 190-3, 195-7, 199-201

Annex Cl.10 ................................. 198

Art.2 …....................................... 190

Art.3(d) ..................... 190, 192, 199

Art.3(e) ....................................... 192

Art.4(1)(a) ................................... 192

Cl.4(i) ........................................ 193

Cl.8(2) ........................................ 191

Cl.5,fn.1 ...................... 192, 196-7

Cl.11 .............................................. 193

Rec.4 …................................... 198

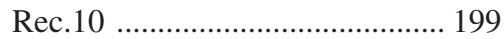

Rec.16 ........................................ 192

Rec.17 ….......................... 190, 192

Rec.18 ….................................... 190

Rec.23 …........................... 190, 192

Commission Decision 2013/C 174/04 of 18 June 2013 on setting up the Commission expert group on cloud computing contracts, $\mathrm{OJ}$ C174/6, 20.06.2013 98 
Commission Implementing Decision (EU) 2016/2295 of 16 December 2016 on the adequate protection of personal data by certain countries, pursuant to Article 25(6) of Directive $95 / 46 / \mathrm{EC}$ of the European Parliament and of the Council (notified under document C(2016) 8353), OJ L344/83, 17.12.2016 159

Commission Implementing Decision (EU) 2016/2297 of 16 December 2016 amending Decisions 2001/ 497/EC and 2010/87/EU on standard contractual clauses for the transfer of personal data to third countries and to processors established in such countries, under Directive 95/46/EC of the European Parliament and of the Council, OJ L34/100, 17.12.2016 159

Commission Implementing Decision (EU) 2016/1250 of 12 July 2016 pursuant to Directive 95/46/EC of the European Parliament and of the Council on the adequacy of the protection provided by the EU-U.S. Privacy Shield (notified under document C(2016) 4176) (Text with EEA relevance), OJ L207/1 [Shield Decision] ... xix, 12-13, 161-2, 167-170, 174, $176-80,183$

Annex II 12,167

Annex IV 183

Art.4(4) 168

Art.4(6) 169

Fn.14 177

Fn.29 178

Fn.31 176

Principle I.5 183

Principle II.2.b 180

Principle II.3 177

Principle II.3.b $178-9$

Principle II.7.d 180

Principle III.6.e 177
Principle III.10.b 178

Rec.6 167

Rec. 14 174,177

Rec. 17 177

Rec. 20 176

Rec. 27 179

Rec. 28 177

Rec. 29 176,180

Rec.64 183

Recs.64-135 ............................... 183

Rec.124 ................................... 168

Recs.136-41 ............................... 169

Rec. 140 ..................................... 183

Rec.141 ...................................... 183

Recs.146-9 ................................. 168

Rec. 152 ....................................... 168

Council Decision 1999/468/EC of 28 June 1999 laying down the procedures for the exercise of implementing powers conferred on the Commission, OJ L184/23, 17.7.1999 351

Joint Committee Decision 83/1999 of 25 June 1999 amending Protocol 37 and Annex XI (Telecommunication services) to the EEA Agreement, OJ L296/41, 23.11.2000

\section{Directives}

Directive 95/46/EC of 24 October 1995 on the protection of individuals with regard to the processing of personal data and on the free movement of such data [Data Protection Directive] (DPD), OJ L281/31, 23.11.1995 ... viii, xvi, 1, 12,36

Art.1 ............................................. 10

Art.2(a) ......................................... 10

Art.2(b) ............................... xix, 11

Art.2(b) ............................. xix, 11

Art.2(d) ..................................... Xvi

Art.2(e) ................................ xix, 13

Art.2(g) ......................... 36, 61, 264

Art.2(h) ................................... 213 


\begin{tabular}{|c|c|}
\hline Art.3(2) ................... 14-15, 54, 165 & $21,156,348$ \\
\hline Art.4 …............. 47-50, 53, 64, 75 & Art.26(1)(a) . \\
\hline Art.4(1)(a) ............... 47-8, 52-3, 77 & Art.26(1)(b) .. \\
\hline Art.4(1)(b) ........................... 48, 73 & Art.26(1)(c) .. \\
\hline Art.4(1)(c) ....... 47, 54, 74-5, 88, 95, & Art.26(1)(d) ......... \\
\hline $123,248,314$ & Art.26(1)(e) \\
\hline Art.4(3) ............................. 48, 50 & Art.26(1)(f) ... \\
\hline Art.6 …..................... 17-18, 156 & Art.26(2) ... 10, 21, 59-60, 187, 190, \\
\hline Art.6(1)(a) ........................................ 156 & $199,204,210,230,342-3$ \\
\hline Art.8 & Art.26(3) ……................ 230, 342 \\
\hline 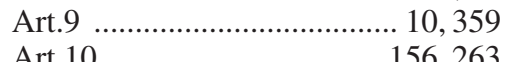 & Art.26(4) ...... xix, 60, 187, 190, 195, \\
\hline Art.10 …......................... 156, 263 & $197,341,343$ \\
\hline Art.11 ............................................ 263 & ….......... 212 \\
\hline Art.11(1) ............................... 156 & Art.28 \\
\hline 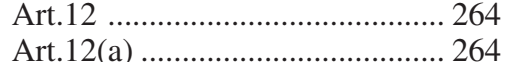 & Art.28(3) \\
\hline Art.12(b) & Art.28(4) \\
\hline Art.16 … 266, 267, 269, 292, 297-8, & Art.28(7) ..... \\
\hline 304 & Art.29 \\
\hline Art.17 ........ xix, 18, 103, 126-7, 129, & Art.31 ........... 160-61, 167, 190, 351 \\
\hline $174,178-9,181,184-6,197$, & Art.31(1) .................................... 351 \\
\hline 199-200, 202, 206, 219, 266, & Art.31(2) ....... 20-21, 336, 338, 342, \\
\hline $267-9,289,295,298,301,304$, & \\
\hline 326 & Art.31(3) ..... \\
\hline Art.17(1) ........................... 267-8, 292 & Art. $48 \ldots \ldots \ldots \ldots$ \\
\hline Art.17(2) ...... 18, 173, 191, 199, 268, & Chap.IV ............. \\
\hline 302 & Chap.VI . \\
\hline Art.17(3) ..... 18, 127, 173, 191, 199, & Rec.9 \\
\hline $268,279,296,298,306$ & Rec. 11 ............... \\
\hline 237 & ........10-11 \\
\hline Art.23 ............. & Rec.30 \\
\hline 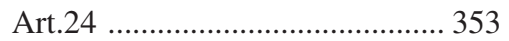 & Rec.38 .............. \\
\hline Art.25 …... 11, 19-20, 36, 45, 46, 49, & Rec. 39 \\
\hline $60,75,79-81,84-5,187$ & Rec.42 \\
\hline $244-5,318,335$ & Rec.43 ................ \\
\hline Art.25(1) ..... 19-21, 59, 72, 85, 199, & Rec.46 ................ \\
\hline $335-6$ & Rec.59 ..... \\
\hline Art.25(2) ............ 20-21, 58-61, 106, & Rec.60 .......... \\
\hline $154-5,165,204,336-8$ & 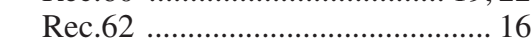 \\
\hline 342 & 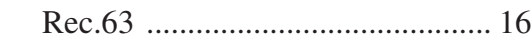 \\
\hline Art.25(3) & Rec.64. \\
\hline Art.25(4) ....... xx, 21, 81, 158-9, 338 & Directive 85/374/EEC of 25 July 1985 \\
\hline Art.25(5) ….......... 21, 25, 149, 338 & on the approximation of the laws, \\
\hline Art.25(6) .... 10, 21, 25, 58, 154, 156, & regulations and administrative \\
\hline $159,161-2,164-5,173$, & provisions of the Member States \\
\hline 187,336 & concerning liability for defective \\
\hline Art.26 .......... 11, 20-21, 36, 46, 187, & products, OJ L210/29, \\
\hline $203,213-15,235,318,342,348$ & 07.08 .1985 . \\
\hline
\end{tabular}


Directive 2000/31/EC of 8 June 2000 on certain legal aspects of information society services, in particular electronic commerce, in the Internal Market [e-Commerce Directive], OJ L178/1, 17.07.2000 280,332

Directive 2002/58/EC of 12 July 2002 concerning the processing of personal data and the protection of privacy in the electronic communications sector [ePrivacy Directive], OJ L201/37, 31.07.2002 $10,169,272,279$,

Art.2(1) .268

Art.4(3) $68,268,279$

Directive 2006/24/EC of 15 March 2006 on the retention of data generated or processed in connection with the provision of publicly available electronic communications services or of public communications networks and amending Directive 2002/58/ EC, [Data Retention Directive] OJ L105/54, 13.04.2006 136, 169

\section{Regulations}

Regulation 45/2001 of 18 December 2000 on the protection of individuals with regard to the processing of personal data by the Community institutions and bodies and on the free movement of such data (CIDPR), OJ L8/1, 12.01.2001 ........ xv, xix, 35-8, 41, $61-3,83,87,89,118-19,192$

Art.2(f) . 36

Art.2(g) 36

Art.9 $36,83,87$

Art.9(1) 36

Art.12 35

Regulation 611/2013 of 24 June 2013 on the measures applicable to the notification of personal data breaches under Directive 2002/ 58/EC of the European Parliament and of the Council on privacy and electronic communications, OJ L173/2, 26.06.2013. 272 Regulation 2016/679 of 27 April 2016 on the protection of natural persons with regard to the processing of personal data and on the free movement of such data, and repealing Directive 95/46/EC [GDPR, General Data Protection Regulation], OJ L119/1,

04.05.2016 ..... xvii-xviii, 1, 9-19, 22-3, 27, 29, 38, 42-3, 46, 54, $58,61,66-8,76,87-8,94$, 103-4, 106, 118, 124, 126, $129,133,145-6,148,150$, $152-5,159-62,165,158$, 168, 178-9, 184-5, 187-8, 192-3, 195-7, 204, 208-9, 210-12, 215-6, 218-9, 220-224, 232, 238-9, 244, 252-3, 256, 258, 264-5, 269, 272, 279-80, 286, 292, 301-5, 314-17, 325, 327-34

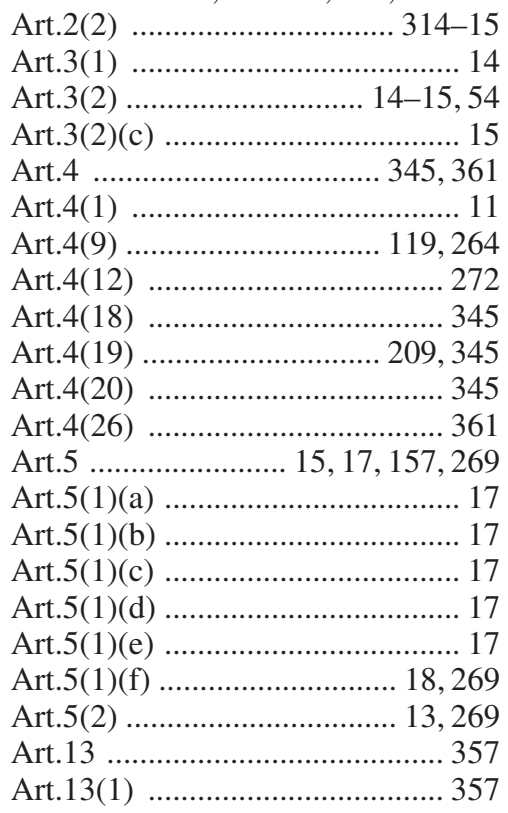




\begin{tabular}{|c|c|}
\hline Art.13(1)(f) ................................. 357 & $157,218-19$ \\
\hline Art.14 & $327-8,335$ \\
\hline Art.14(1) & Art.45 …........ 106, 153-4, 168,336 \\
\hline Art.14(1)(f) .................. 23, 63, 358 & Art.45(1) .............................. 336 \\
\hline Art.15 & Art. $45(2) \ldots \ldots$. \\
\hline Art.15(1)(c) …............................... 63 & $160,217,219,337$ \\
\hline . 23, 358 & Art.45(2)(b) .. \\
\hline Art.18 & Art.45(2)(c) .............. \\
\hline 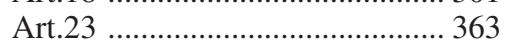 & Art.45(3) …........ 161, 168, 338, 342 \\
\hline Art.23(1) ................................. 363 & Art.45(4) ........ \\
\hline 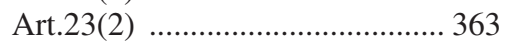 & Art.45(5) ......... \\
\hline Art.24(3) & Art.45(6) ........ \\
\hline Art.25(3) ….............................. 211 & Art.45(7) . \\
\hline Art.28 ..... 129, 184, 185-6, 219, 279, & Art.45(8) \\
\hline 302,356 & $161,168,339$ \\
\hline Art.28(1) ... & $. .61,188-9,342$ \\
\hline Art.28(3) …...... 127, 298, 296, 356 & Art.46(1) .......... \\
\hline Art.28(3)(a) ........................ 129, 356 & Art.46(2) ........... \\
\hline 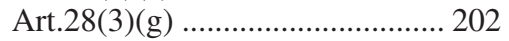 & Art.46(2)(a) .... \\
\hline Art.28(5) ........ & Art.46(2)(b) ... \\
\hline 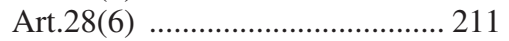 & Art.46(2)(c) ... \\
\hline Art.29 …............... 127, 269, 304 & Art.46(2)(d) ... \\
\hline Art.30 ................ & $\ldots 189,210,343$ \\
\hline Art.30(1) .......... & $\ldots 189,210,343$ \\
\hline Art.30(1)(d) .......................63, 356 & Art.46(3) ......... \\
\hline Art.30(1)(e) .... & Art.46(3)(a) .. \\
\hline Art.30(2) …........................ 356 & Art.46(4) ............ \\
\hline Art.30(2)(c) ............ 14-15, 23, 356 & .. 192, 209-10,343 \\
\hline Art.32 & Art.47 ...................... \\
\hline Art.32(1) ............................ 269, 298 & Art.47(1) ......... \\
\hline 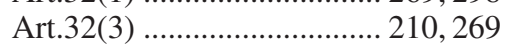 & Art.47(1)(a) ... \\
\hline 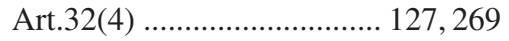 & Art.47(1)(b) .... \\
\hline Art.33 .............. & Art.47(1)(c) ... \\
\hline Art.33(2) & Art.47(2) ........ \\
\hline 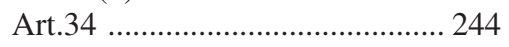 & Art.47(2)(a) .... \\
\hline Art.34(3)(a) ................................. 279-80 & Art.47(2)(b) ... \\
\hline Art.35(8) …................................ 211 & Art.47(2)(c) ... \\
\hline 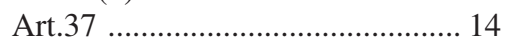 & Art.47(2)(d) .... \\
\hline Art.40 ….............................. 357 & Art.47(2)(e) .... \\
\hline Art.40(1) (......................................... 212 & Art.47(2)(f) ...... \\
\hline 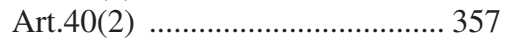 & 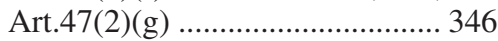 \\
\hline 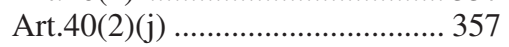 & Art.47(2)(h) .... \\
\hline Art.41 ......................................... 210 & Art.47(2)(i) ...... \\
\hline Art.42 …............................. 357 & Art.47(2)(j) ...... \\
\hline 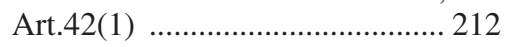 & 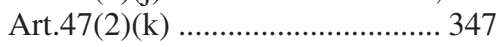 \\
\hline Art.42(2) (.................................... 357 & Art.47(2)(1) ....... \\
\hline Art.42(5) (................................... 210 & Art.47(2)(m) ... \\
\hline 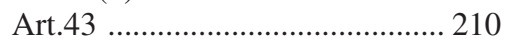 & 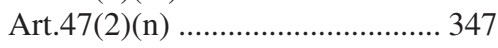 \\
\hline
\end{tabular}


Art.47(3) 347

Art.48 ... 110, 119, 208, 213, 314-15,

317,352

Art.49

348

Art.49(1)

Art.49(1)(a)

Art.49(1)(b)

Art.49(1)(c)

Art.49(2)

Art.49(2)(g)

Art.49(3)

Art.49(3)(a)

Art.49(3)(b)

Art.49(3)(c)

Art.49(3)(d)

Art.49(4)

Art.49(4)(e)

Art.49(4)(f)

Art.49(4)(g)

Art.49(5)

Art.49(6)

Art.50

Art.50(a)

Art.50(b)

Art.50(c)

Art.50(d)

Art.53

Art.57

Art.57(1)

Art.57(1)(j)

Art.57(1)(r)

Art.57(1)(s)

Art.58

Art.58(1)(a)

Art.58(1)(b)

Art.58(2)

Art.58(2)(g)

Art.58(2)(h)

Art.58(2)(i)

Art.58(2)(j)

Art.63

Art.64

Art.64(1)

Art.64(1)(d)

Art.64(1)(e)

Art.64(1)(f)

Art.65

Art.66
$215,348,349$

215,348

348

348

63,349

349

349

348

348

348

348

216,348

349

349

349

161,339

349

258,358

358

358

358

358

252

353

353

353

353

353

354

16

16

354

354

354

354

$16,63,354$

16

16,354

354

354

354

354

16

16
Art.67 …................................... 16

Art.68 …...................................... 16

Art.70 ….................................. 355

Art.70(1) ................................... 355

Art.70(1)(e) ........................ 16, 355

Art.70(1)(I) ................................ 209

Art.70(1)(i) ................................. 355

Art.70(1)(j) ...................... 216, 355

Art.70(1)(v) .............................. 355

Art.70(s) …................................. 160

Art.71 ……................................... 355

Art.71(1) ................................. 355

Art.79(2) (................................. 184

Art.80 …................................. 238

Art.82 …..................................... 14

Art.82(2) .................................. 127

Art.82(3) .................................. 180

Art.83 ……....................................... 353

Art.83(2)(j) ................................. 210

Art.83(4) ............................. 17, 269

Art.83(4)(a) ….............. 244, 269-70

Art.83(5) ............................. 17, 353

Art.83(5)(a) ................................ 269

Art.83(5)(c) ................ 63, 252, 353

Art.83(5)(e) ….................. 252, 353

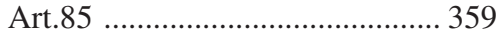

Art.85(2) .......................... 161, 359

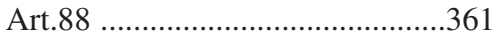

Art.88(1) .........................................361

Art.88(2) ............................ 161, 361

Art.93 ….................................... 351

Art.93(1) ................................... 351

Art.93(2) ................ 160-1, 188, 351

Art.93(3) ................................... 351

Art.96 ........................ 22, 352, 362

Art.97 ............................... 161, 362

Art.97(1) .................... 23, 161, 362

Art.97(2) ................................... 362

Art.97(2)(a) ....................... 23, 362

Ch.V …...................................... 22

Rec. 2 ............................................ 13

Rec. 14 ........................................... 13

Rec. 21 ....................................... 280

Rec.48 …................................. 361

Rec.57 .................................... 301

Rec.101 .................. 63, 218-19, 336

Rec.102 ….......................... 22, 353

Rec. 103 …................................. 339 


\begin{tabular}{|c|c|}
\hline & \\
\hline ec. 105 & 1 \\
\hline ec. 106 & 161 \\
\hline ec. 107 & \\
\hline 8 & \\
\hline ec. 109 & \\
\hline ec. 110 & .209, \\
\hline ec.111 & \\
\hline ec. 112 & \\
\hline ec. 11 & \\
\hline ec. 1 & .... 19, 119, \\
\hline 1 & \\
\hline & \\
\hline$c .15$ & 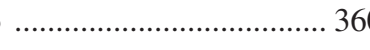 \\
\hline
\end{tabular}

\section{EU POLICY DOCUMENTS}

\section{EU Council}

6032/94, Note from Presidency to

Working Party on Economic

Questions (Data Protection),

Subject: Amended proposal for a

Council Directive on the

protection of individuals with

regard to the processing of

personal data and on the free movement of such data,

29.03.1994

6648/94, Outcome of Proceedings of

Working Party on Economic

Questions (Data Protection) on 21

and 22 April 1994, Subject:

Amended proposal for a Council

Directive on the protection of individuals with regard to the processing of personal data and on the free movement of such data,

01.05.1994 304
7695/93, Cover note from Belgian delegation dated 30 June 1993 to Mr Niels ERSBØLL, Secretary-General of the Council of the European Communities, Subject: Proposal for a Directive on the protection of individuals with regard to the processing of personal data and on the free movement of such data, 01.07.1993

$8651 / 91$, Outcome of Proceedings of Working Party on Economic Questions (Data Protection) on 7 and 8 October 1991, Subject:

Protection of Individuals in relation to the processing of personal data in the Community and information security, 30.10 .1991 29,49

9565/2015, Note from Presidency to Council, Subject: Proposal for a Regulation of the European Parliament and of the Council on the protection of individuals with regard to the processing of personal data and on the free movement of such data (General Data Protection Regulation) Preparation of a general approach, 11.06.2015 209

9788/15, Outcome of Proceedings from General Secretariat of the Council to Delegations, Subject: Proposal for a Regulation of the European Parliament and of the Council on the protection of individuals with regard to the processing of personal data and on the free movement of such data (General Data Protection Regulation) Preparation of a general approach, 11.06.2015 ... 54, 119, 158-9, 186, 
10680/15, Note from Presidency to JHA

Counsellors on Information

Exchange and Data Protection

(DAPIX) MIXED COMMITTEE

(EU-Iceland/Liechtenstein/

Norway/Switzerland), Subject:

Proposal for a Regulation of the

European Parliament and of the

Council on the protection of individuals with regard to the processing of personal data and on the free movement of such data (General Data Protection Regulation) - Presidency debriefing on the outcome of the trilogue on 14 July 2015 , 15.07.2015

Common Position No.1/95 of 20

February 1995 with a view to adopting Directive 95/46/EC on the protection of individuals with regard to the processing of personal data and on the free movement of such data (CP), OJ C93/1, 13.04.1995 ...... xvi, 35, 46, 50-51, 53, 59-60, 267-8, 292

\section{EU Parliament}

A7-0402/2013, Report on the proposal for a regulation of the European Parliament and of the Council on the protection of individuals with regard to the processing of personal data and on the free movement of such data (General Data Protection Regulation) (COM(2012)0011 - C7-0025/ 2012 - 2012/0011(COD))

PE 501.927v05-00, 22.11.2013.:

P7_TA(2014)0230, Resolution of 12 March 2014 on the US NSA surveillance programme, surveillance bodies in various Member States and their impact on EU citizens' fundamental rights and on transatlantic cooperation in Justice and Home Affairs (2013/ 2188(INI)), P7_TA(2014)0230); minutes of sitting of 12 March 2014, 2015/C85/03, OJ C85/198 para.8.23, 12.03.2015 .... 163, 313

Resolution on transatlantic data flows 2016/2727(RSP) 167

\section{EU Pre-Legislative Documents}

COM(90)314 final, Commission Communication on the protection of individuals in relation to the processing of personal data in the Community and information security, 13.09.1990 (containing SYN 287 - Proposal for a Council Directive concerning the Protection of Individuals in relation to the Processing of Personal Data), (1990-Proposal) OJ C277/3, 5.11.1990 .... xv, 34-5, 48-55, 58-60, 132, 144, $264,267,271,275,319$

Art.4(1)(a) .................................... 48

Art.4(1)(b) .............................. 48-9

Art.4(2) .......................... 48-9, 51-2

Art.4(3) ........................... 48, 50-51

Art.22 …........................................... 49

Art.24 .......................... 49-50, 53

Art.25(1) ..................................... 59

COM(92)422 final SYN 287,

Amended proposal for a

Council Directive on the protection of individuals with regard to the processing of personal data and on the free movement of such data (1992-Proposal), 15.10.1992 ... xv, 35, 46-7, 50-53, $58-60,143,262-8,289$, $292,304,319$ Art.4 ......................... 47, 50-3, 143 Art.16 ......................................... 304 Art.27(1) ..................................... 60 
COM(1999)337 final, Proposal for a Regulation of the European Parliament and of the Council on the protection of individuals with regard to the processing of personal data by the institutions and bodies of the Community and on the free movement of such data, OJ C376/E/24, 28.12.1999 36

$\operatorname{COM}(2003) 265$ final, Report from the Commission - First report on the implementation of the Data Protection Directive (95/46/EC), 15.05.2003 ....... 15, 153, 187, 220, 230, 235, 239-40, 247

$\operatorname{COM}(2010) 609$ final, Communication from the Commission to the European Parliament, the Council, the Economic and Social Committee and the Committee of the Regions - A comprehensive approach on personal data protection in the European Union, 04.11.2010 .... 153-4, 158, $208,224,241$

$\operatorname{COM}(2012) 9$ final, Communication from the Commission to the European Parliament, the Council, the European Economic and Social Committee and the Committee of the Regions Safeguarding Privacy in a Connected World A European Data Protection Framework for the 21st Century, 25.01.2012 _...... 208 COM(2012)011 final, Proposal for a Regulation of the European Parliament and of the Council on the protection of individuals with regard to the processing of personal data and on the free movement of such data (General Data Protection Regulation), 25.01.2012 $47,208,215,301$
COM(2012)529 final, Communication from the Commission to the European Parliament, the Council, the European Economic and Social Committee and the Committee of the Regions Unleashing the Potential of Cloud Computing in Europe,

27.09.2012

COM(2013)846 final, Communication from the Commission to the European Parliament and the Council - Rebuilding Trust in EU-US Data Flows, 27.11.2013 313

$\operatorname{COM}(2013) 847$ final, Communication from the Commission to the European Parliament and the Council on the Functioning of the Safe Harbour from the Perspective of EU Citizens and Companies Established in the EU, 27.11.2013 $163,254-5$

$\operatorname{COM}(2014) 72$ final, Communication from the Commission to the European Parliament, the Council, the European Economic and Social Committee and the Committee of the Regions Internet Policy and Governance: Europe's role in shaping the future of Internet Governance, 12.02.2014 315

COM(2014)442 final, Communication from the Commission to the European Parliament, the Council, the European Economic and Social Committee and the Committee of the Regions Towards a thriving data-driven economy, 02.07.2014 5,112 
COM(2015)192 final, Communication from the Commission to the European Parliament, the Council, the European Economic and Social Committee and the Committee of the Regions - A Digital Single Market Strategy for Europe, 06.05.2015 .... 5, 112, 211 $\operatorname{COM}(2017) 7$ final, Communication from the Commission to the European Parliament and the Council, Exchanging and Protecting Personal Data in a Globalised World, 10.01.2017 114,196

COM(2017)9 final, Communication from the Commission to the European Parliament and the Council, Building a European Data Economy, 10.01.2017 .... 143 SEC(2004)1323, Commission Staff Working Document - The implementation of Commission Decision 520/2000/EC on the adequate protection of personal data provided by the Safe Harbour, 20.10.2004 163

SEC(2006)95, Commission Staff Working Document on the implementation of the Commission decisions on standard contractual clauses for the transfer of personal data to third countries (2001/497/EC and 2002/16/EC), 20.01.2006 ... 190, 195-7, 230-31

SEC(2012)72 final, Commission Staff

Working Paper - Impact

Assessment Accompanying the document Regulation of the European Parliament and of the Council on the protection of individuals with regard to the processing of personal data and on the free movement of such data (General Data Protection Regulation) and Directive of the European Parliament and of the Council on the protection of individuals with regard to the processing of personal data by competent authorities for the purposes of prevention, investigation, detection or prosecution of criminal offences or the execution of criminal penalties, and the free movement of such data, 25.01.2012 .........13, $220,223,240,257$

Annex 1 7,13

Annex 2 $25,82,101,129,158$, 204, 220-21

Annex 4 29, 206, 222

Annex 5 215

Annex 8 228

SWD(2014)214 final, Commission

Staff Working Document - Report on the Implementation of the Communication 'Unleashing the Potential of Cloud Computing in Europe' Accompanying the document Communication from the Commission to the European Parliament, the Council, the European Economic and Social Committee and the Committee of the Regions 'Towards a thriving data-driven economy'

(COM(2014)442 final),

02.07.2014 63

SWD(2015)100, Commission Staff

Working Document - A Digital Single Market Strategy for Europe - Analysis and Evidence Accompanying the document Communication from the Commission to the European Parliament, the Council, the European Economic and Social Committee and the Committee of the Regions - A Digital Single Market Strategy for Europe (COM(2015)192 final), 06.05.2015 6,112 


\section{WP29 Opinions}

WP4: Discussion Document: First orientations on transfers of personal data to third countries possible ways forward in assessing adequacy, 26.06.1997 44 , 155-9, 159, 188, 227

WP9: Working Document: Preliminary views on the use of contractual provisions in the context of transfers of personal data to third countries, 22.04.1998 64,157 , 238,253

WP12: Transfers of personal data to third countries: Applying Articles 25 and 26 of the EU data protection directive, 24.07.1998 ...... 17, 44, 62, 64, 73, 154-7, 159, 187-8, 213-15, $223,238,248,259,263,304$

WP14: Second Annual Report. 30.11.1998 227,234

WP15: Opinion 1/99 concerning the level of data protection in the United States and the ongoing discussions between the European Commission and the United States Government, 26.01.1999 ....... 162

WP22: Opinion 5/99 on the level of protection of personal data in Switzerland, 07.09.1999 217

WP27: Opinion 7/99 on the Level of Data Protection provided by the 'Safe Harbor' Principles as published together with the Frequently Asked Questions (FAQs) and other related documents on 15 and 16 November 1999 by the US Department of Commerce, 03.12.1999 163,180

WP32: Opinion 4/2000 on the level of protection provided by the 'Safe Harbor Principles,' 16.05.2000 180

WP35: Third Annual Report , 22.12.1999 245
WP38: Opinion 1/2001 on the Draft Commission Decision on Standard Contractual Clauses for the transfer of Personal Data to third countries under Article 26(4) of Directive 95/46, 26.01.2001

WP39: Opinion 2/2001 on the adequacy of the Canadian Personal Information and Electronic Documents Act, 26.01.2001 .. 218

WP40: Opinion 3/2001 on the level of protection of the Australian Privacy Amendment (Private Sector) Act 2000, 26.01. 2001 158

WP47: Opinion 7/2001 on the Draft Commission Decision (version 31 August 2001) on Standard Contractual Clauses for the transfer of Personal Data to data processors established in third countries under Article 26(4) of Directive 95/46, 13.09.2001 ... 25, 64, 199

WP48: Opinion 8/2001 on the processing of personal data in the employment context, 13.09.2001 214

WP54: Fifth Annual Report, 06.03.2002 78,245

WP56: Working document on determining the international application of EU data protection law to personal data processing on the Internet by non-EU based web sites, 30.5.2002 $13,52,64$, 248-9

WP74: Working Document on Transfers of personal data to third countries: Applying Article 26 (2) of the EU Data Protection Directive to Binding Corporate Rules for International Data Transfers, 03.06.2003 
WP107: Working Document Setting Forth a Co-Operation Procedure for Issuing Common Opinions on Adequate Safeguards Resulting From 'Binding Corporate Rules,' 14.04.2005 205

WP108: Working Document

Establishing a Model Checklist

Application for Approval of

Binding Corporate Rules, 14.04.2005 205

WP114: Working document on a common interpretation of Article 26(1) of Directive 95/46/EC of 24 October 1995, 25.11.2005 ...... 19, $46,60,152,187,213-4,220$,

WP128: Opinion 10/2006 on the processing of personal data by the Society for Worldwide Interbank Financial Telecommunication (SWIFT), 22.11.2006 90, ....... 92, 116,223

WP133: Recommendation 1/2007 on the Standard Application for Approval of Binding Corporate Rules for the Transfer of Personal Data, 10.01.2007 $205,345-7$

WP136: Opinion 4/2007 on the concept of personal data, 20.06.2007 282

WP148: Opinion 1/2008 on data protection issues related to search engines, 04.04.2008 52

WP153: Working Document setting up a table with the elements and principles to be found in Binding Corporate Rules, 24.06.2008 $205,345-7$

WP154: Working Document setting up a framework for the structure of Binding Corporate Rules, 24.06.2008 205

WP163: Opinion 5/2009 on online social networking, 12.06.2009 ...9
WP168: The Future of Privacy: Joint contribution to the Consultation of the European Commission on the legal framework for the fundamental right to protection of personal data, 01.12.2009 ..... 205, 208, 241

WP169: Opinion 1/2010 on the concepts of 'controller' and 'processor,' 16.02.2010 9

WP171: Opinion 2/2010 on online behavioural advertising, 22.06.2010 92

WP176: FAQs in order to address some issues raised by the entry into force of the EU Commission Decision 2010/87/EU of 5 February 2010 on standard contractual clauses for the transfer of personal data to processors established in third countries under Directive 95/46/EC, 12.07.2010 ................. 190-3, 200

WP179: Opinion 8/2010 on applicable law, 16.12.2010 ...... 47-8, 50-53, $64,74,95,248-9,314$

WP182: Opinion 11/2011 on the level of protection of personal data in New Zealand, 04.04.2011 ...... 217

WP187: Opinion 15/2011 on the definition of consent, 13.07.2011

WP195: Working Document 02/2012 setting up a table with the elements and principles to be found in Processor Binding Corporate Rules, 06.06.2012 ...... 207, 345-7

WP196: Opinion 05/2012 on Cloud Computing, 01.07.2012 .... 16-17, 61, 92, 95-6, 99-100, 107, $127-9,142,163,171-3$, 199-200, 211-2, 265-6, 268, 270, 272-3, 282, 289-92, 297, 300, 302, 305,329 
WP204: Explanatory Document on the Processor Binding Corporate Rules, 19.04.2013, revised 22.05.2015 207-8, 314

WP211: Opinion 01/2014 on the 'Application of necessity and proportionality concepts and data protection within the law enforcement sector,' 27.02.2014 18,317

WP212: Opinion 02/2014 on a referential for requirements for Binding Corporate Rules submitted to national Data Protection Authorities in the EU and Cross Border Privacy Rules submitted to APEC CBPR Accountability Agents, 27.02.2014 40

WP213: Opinion 03/2014 on 'Personal Data Breach Notification,' 25.03.2014 $266,272,289$

WP215: Opinion 04/2014 on surveillance of electronic communications for intelligence and national security purposes, 10.04.2014 $15,183,196,306$, $313-4,317$

WP216: Opinion 05/2014 on Anonymisation Techniques, 10.04.2014 $10,282-3,286$

WP217: Opinion $06 / 2014$ on the notion of legitimate interests of the data controller under Article 7 of Directive 95/46/EC, 09.04.2014 216

WP218: Statement on the role of a risk-based approach in data protection legal frameworks, 30.05.2014

WP219: Opinion 7/2014 on the protection of personal data in Quebec, 04.06.2014 158,218

WP222: Statement on the results of the last JHA meeting, 17.09.2014 216

WP226: Working Document Setting Forth a Co-Operation Procedure for Issuing Common Opinions on 'Contractual clauses' Considered as compliant with the EC Model

Clauses, 26.11.2014 195

WP227: Joint statement of the European

Data Protection Authorities

assembled in the Article 29

Working Party, 26.11.2014 ... 183, 306

WP228: Working Document on surveillance of electronic communications for intelligence and national security purposes, 05.12.2014 ..... 183, 196, 205, 207, $213,306,347$

WP237: Working Document 01/2016 on the justification of interferences with the fundamental rights to privacy and data protection through surveillance measures when transferring personal data (European Essential Guarantees), 13.04.2016 165,170

WP238: Opinion 01/2016 on the EU U.S. Privacy Shield draft adequacy decision, 13.04.2016 167-8

\section{NATIONAL LEGISLATION}

\section{Australia}

Privacy Act 1988 $25,118,158-9$ 222,262

\section{Canada}

Personal Information Protection and Electronic Documents Act 2000 (PIPEDA) ....... 38-40, 98-9, 148, 158-9, 218, 262, 281, 286, 327

\section{Germany}

Federal Data Protection Act 2003 118,281 


\section{Hong Kong \\ Personal Data (Privacy) Ordinance 1995} 222

\section{Malaysia}

Personal Data Protection Act 2010 145

\section{Singapore}

Data Protection Act 2012 40,262

Personal Data Protection Regulations 2014 75

\section{Switzerland}

Federal Act on Data Protection 1992 118,217

\section{United Kingdom}

Data Protection Act 1998 117-18,

\section{United States}

Electronic Communications Privacy Act 198618 U.S.C. $\S 2510-22$ (1986) 94

Federal Information Security Management Act 2002 (FISMA)

Pub. L. No.107-347, 116

Stat.2899, as amended $265-6$

Federal Information Security Modernization Act 2014 Pub. L.

No.113-283, 128 Stat.3073 .... 266

Foreign Intelligence Surveillance Act 1978 (FISA) Pub. L. No.95-511, 92 Stat.1783, as amended ..... xvii, 55, 88, 119, 224, 314-15, 317, 352
Health Insurance Portability and Accountability Act 1996 (HIPAA) Pub. L. No.104-191, 110 Stat.1936, as amended 279

International Communications Privacy Act 2016 (ICPA) 94, 111

International Traffic In Arms Regulations (ITAR) 22 C.F.R $\S \S 120-130$, as amended ......... 282 Judicial Redress Act 2016 Pub. L. No.114-126, 130 Stat. 285 ..... 313

Law Enforcement Access to Data Stored Abroad Act 2015 (LEADS Act) 94

PATRIOT Act 2001 (USA PATRIOT Act, Uniting and Strengthening America by Providing Appropriate Tools Required to Intercept and Obstruct Terrorism Act of 2001) Pub. L. No.107-56, 115 Stat.272, as amended $99,117,141$, $182-3,320$

Stored Communications Act 201218

U.S.C. $\$ 2701-2712$

(2012) 93-4

USA Freedom Act 2015 117

\section{INTERNATIONAL} CONVENTIONS,

\section{AGREEMENTS AND TREATIES}

Charter of Fundamental Rights of the European Union 2000 [OJ C364/1, 18.12.2000] $\mathrm{xv}, 10,164-5$ Art.7 313

Art.8 $164,292,313$

Art.8(3) 136

Convention 108 on the Protection of Individuals with regard to Automatic Processing of Personal Data 1981 (Council of Europe) [ETS No. 108] 
(Convention108) .... xvi, 24, 32-5, $38,41-4,52,57,61-3$, $65-8,72,75,93,119,124$, $132,149,157,192,258$,

319

Art.1

13,34

Art.12 $29,33-4$

Art.12(3) .66-7

Art.12(3)(b) $37-8,44$

Art.24 34

Art.30(1)(b) 58

Art.30(6) 58

Additional Protocol to Convention 108 2001 [ETS No. 181]

(Convention108-AP) $36-8$ 40-41, 61-3, 89, 124, 157

Art.2 37-8

Art.2(1) 38

Explanatory Report 1981 [ETS No.

181] (Convention108-ER)

Para. 1

Para. 8 32

Para.9 24, 29-30, 44, 149

Para. 20 32

Para. 21 33

Para.23 34

Para. 26 13

Para.30 50

Para.63 33,72

Para.64

Para.67

Para.69

Para. 70

Para.91 45

Explanatory Report to Additional

Protocol

(Convention108-APER) ... 36-8

European Convention for the Protection of Human Rights and

Fundamental Freedoms 1950

[ETS No. 155] (ECHR) ... xvii, 10, $33,165,313$

Art.8 $10,292,313$

Art. 10 33

General Agreement on Trade in Services. Marrakesh Agreement Establishing the World Trade
Organization, Annex 1B, 15 April

1994 (GATS) xvii, 114

\section{OECD}

Guidelines on the Protection of Privacy and Transborder Flows of Personal Data, 1980 (OECD

Guidelines) ....... xviii, xix, 18-19, 24, 29-35, 38, 40-41, 44-5, 57, 61-2, 67, 71, 75, 93, 113, 227

Guidelines on the Protection of Privacy and Transborder Flows of Personal Data, 1980: Explanatory

Memorandum (OECD-ExplanMem) .... xviii, 24, $28,30-32,44-5,75,144$

Guidelines governing the Protection of Privacy and Transborder Flows of Personal Data, 2013 (OECD

Guidelines-2) xviii, 41,45

Trade in Services Agreement (TISA) (draft) $113-4$

Transatlantic Trade and Investment Partnership (TTIP) (draft) ...... 114

Treaty on European Union (consolidated) OJ C83/13, 30.03.2010 165

Treaty on the Functioning of the European Union (consolidated) OJ

C83/47, 31.03.2010 165

US-Ireland Mutual Legal Assistance

Treaty (MLAT) 2001 93-4

\section{MISCELLANEOUS DOCUMENTS}

\section{APEC}

Cross Border Privacy Rules

(CBPR) 39-40, 206

Privacy Framework ....... 19, 29, 39-40, 221-2, 262 
International Standards Organisation ISO/IEC 27017:2015 - Information technology - Security techniques - Code of practice for information security controls based on ISO/ IEC 27002 for cloud services $211-2$
ISO/IEC 27018:2014 - Information technology - Security techniques - Code of practice for protection of personally identifiable information (PII) in public clouds acting as PII processors ..... 211-2 
W. Kuan Hon - 9781786431974

Downloaded from PubFactory at 04/26/2023 01:01:51PM via free access 